\title{
STUDI ADAPTASI PERTUMBUHAN DAN PRODUKSI BEBERAPA VARIETAS PADI (Oryza sativa) DI TANAH GAMBUT
}

Oleh: Edi Pardani ${ }^{1}$, Zinatal Hayati ${ }^{2}$, dan Melia Aktrinisia ${ }^{3}$

Program Studi Agroteknologi, Fakultas Pertanian

Universitas Islam Indragiri

\begin{abstract}
ABSTRAK
Penelitian ini bertujuan untuk mengetahui Studi Adaptasi Pertumbuhan Dan Produksi Beberapa Varietas Tanaman Padi (Oriza sativa) Di Tanah Gambut Penelitian ini dilaksanakan di Jalan SKB Tembilahan Kota Inhil Propinsi Riau bulan Juni sampai Maret 2013.

Rancangan yang digunakan dalam penelitian ini adalah Rancangan Acak Kelompok (RAK) dengan 5 perlakuan dan 3 ulangan. Perlakuan tersebut adalah beberapa varietas tanaman padi. Sebagai berikut Varietas Lantik Bamban, Varietas Batang Piaman, Varietas Ciherang, Varietas Cisadane, Varietas Pandan Wangi.

Parameter yang diamati adalah : tinggi tanaman padi, jumlah anakan produktif, jumlah mulai perumpun, jumlah gabah bernas pemalai, produksi perumpun. Data yang didapat dianalisis secara statistik, apa bila $F$ hitung lebih besar dari F tabel dilanjutkan dengan uji Tukey HSD taraf $5 \%$.

Hasil penelitian yang telah dilakukan dapat diambil kesimpulan yaitu sebagai berikut : Jumlah produksi tanaman perplot tertinggi yaitu varietas Cisadane dengan jumlah gabah perumpun $1.008,931$ (butir) dan varietas yang cocok ditanam ditanah gambut adalah varietas Cisadane.
\end{abstract}

Kata Kunci : padi, studi, gambut 


\section{PENDAHULUAN}

Padi merupakan komoditas tanaman pangan utama di Indonesia karena sebagian besar penduduk indoesia makanan pokoknya adalah beras. Permintaan akan bersar terus meningkat dari waktu kewaktu seiring bertambahnya jumlah penduduk. Indonesia merupakan Negara produsen juga konsumen beras di dunia. Oleh karena itu sampai saat ini, padi merupakan komoditas strategis yang tetap mendapatkan prioritas penanganan dalam pembangunan pertanian.

Produksi padi di Kabupaten Indragiri Hilir tahun 2010 mencapai 1109.902,42 ton setara dengan 69.018, 72 ton beras, sementara kebutuhan beras sebanyak $71.475,96$ ton, dengan demikian masih kekurangan sebesar 2.457,24 ton beras (BPS, 2010). Berdasarkan data tersebut peningkatan produksi perlu diupayakan untuk mengimbangi laju pertambahanpenduduk dan mengurangi impor beras sehingga ketahanan pangan nasional dapat dipertahankan.

Gambut terbentuk dari sersah organik yang terkomposisi secara anaerobik dimana laju penambahan bahan organik lebih tinggi dari pada laju dekomposisinya. Gambut Obrogen di indonesia terbentuk dari sersah vegetasi hutan yang berlangsung selama ribuan tahun, sehingga status keharaannya rendah dan mempunyai kandungan kayu yang tinggi (Radjaguguk, 1990).

Adaptasi varietas sebagai suatu keragaman hasil di lintas lokasi rata-rata dari musim ke musim disuatu lokasi, stabilitas dan adaptasi akan mempunyai hubungan yang erat jika adanya interaksi varietas dengan lingkungan disebabkan oleh peubah lingkungan yang tidak bisa di ramalkan seperti jenis tanah dan ketinggian tempat (Dedi, 2004) Setiap varietas memiliki ciri morfologis dan adaptasi dengan memanfaatkan lingkungan tempat tumbuhnya.

Kondisi lingkungan yang beragam memerlukan teknologi spesifik dalam meningkatkan produksi tanaman. Salah satunya dengan penggunaan varietas yang sesuai dengan lingkungan tumbuh tanaman pengujian beberapa varietas pada tempat yang berbeda menunjukkan bahwa terdapat respon yang berbeda antar varietas terhadap lingkungan tumbuhnya (Reni, 2005).

Penelitian bertujuan untuk pengembangan pertanian dilahan gambut dan memilih varietas padi yang baik.

\section{TINJAUAN PUSTAKAN}

\subsection{Tanaman Padi}

Sistematik (taksonomi) tumbuhan, kedudukan tanaman padi di klasifikasikan sebagai berikut.

$\begin{array}{ll}\text { Kingdom } & \text { : Plantae. } \\ \text { Divisio } & \text { : Spermatophyta } \\ \text { Subdivisio } & : \text { Angiospermae } \\ \text { Kelas } & : \text { Monocotyledoneae } \\ \text { Ordo } & \text { : Poales } \\ \text { Familia } & \text { : Poaceae } \\ \text { Genus } & : \text { Oryza } \\ \text { Spesies } & : \text { Oryza sativa }\end{array}$

(Van Stenis 1981).

Padi termasuk dalam suku padi-padian atau Poaceae (sinonim : Gramine atau Glumiflorae) tanaman semusim, berakar serabut, batang sangat pendek, struktur berupa batang yang terbentuk dari rangkaian pelepah daun yang saling menopang, daun semprna dengan pelepah tegak, berbentuk lanset, warna hijau muda hingga hijau tua, berurat daun sejajar, tertutupi oleh rambut yang pendek dan jarang, bunga tersusun majemuk, tipe melai bercabang, satuan bunga disebut floret yang terletask pada satu spikelet yang duduk pada panikula, buah tipe bulir atau kariopsis tang tidak dapat dibedakan mana buah dan bijinya, bentuk hampir bulat hingga lonjong, ukuran $3 \mathrm{~mm}$ hingga $15 \mathrm{~mm}$, tertutup oleh palea dan lemma yang dalam bahasa sehari-hari deisebut sekam ( Wikipedia, 2011).

perkembangan akar tanaman padi mengarah ke bawah dan sedikit ke arah sanmping. Akar tumbuh di sekeliling pangkal batang yang selanjutnya menyebar ke semua arah panjang akar pada saat penanaman sekitar $4 \mathrm{~cm}$ sampai $5 \mathrm{~cm}$ belum menyebar dan setelah satu minggu berikutnya akar mulai tumbuh menyebar. pada saat penyiangan pertama yaitu padi berumur 
empat minggu penyebaran akar mencapai radius $6 \mathrm{~cm}$ sampai $7 \mathrm{~cm}$, dan pada saat dewasa mencapai $10 \mathrm{~cm}$ sampai $15 \mathrm{~cm}$. Letak susunan perakaran tidak terlalu dalam sekitar $20 \mathrm{~cm}$ sampai $30 \mathrm{~cm}$ dengan 6 arah penyebaran tidak terus ke dalam melainkan ke samping. Ketinggian padi pada saat penanaman skitar $20 \mathrm{~cm}$. Setelah berumur empat minggu (penyiangan pertama) ketinggian batang padi rata-rata sekitar 30 sampai $35 \mathrm{~cm}$. Jumlah batang padi setelah berumur satu bulan bertambah kurang lebih mencapai 20 batang (Surowinoto 1980).

\subsection{Syarat Tumbuh tanaman Padi}

Pertumbuhan tanaman padi dipengaruhi oleh beberapa faktor antara lain : iklim yang terdiri dari curah hujan dengan rata-rata $200 \mathrm{~mm} /$ bulan atau lebih, suhu lebih dari $23{ }^{\circ} \mathrm{C}$, tinggi tempat berkisar 0 650 meter dpl, sinar matahari, angin yang membantu proses penyerbukan dan pembuahan dan musim. Faktor yang lain adalah tanah yang terdiri dari tekstur tanah, struktur tanah pada ketebalan lapisan atas antara 18-22 cm, dengan $\mathrm{pH}$ antara 4-7, seta air dan udara dalam tanah (Haryoko, W. 2006).

Tumbuhan padi adalah tumbuhan yang membutuhkan banyak air (waterplant). tanaman padi dapat juga tumbuh di tanah kering asalkan curah hujan mencukupi kebutuhan tanaman. Untuk tanaman padi di lahan basah kebutuhan akan air sangat penting yaitu untuk melunakkan tanah sebagai media tumbuh, memudahkan dalam penyerapan unur hara dan juga karena sifat tanaman itu sendiri yang merupakan tanaman air. Selain fungsi di atas penggenangan air juga dapat berfungsi membunh beberapa jenis gulma (Seregar 1981 dan Pirhatman 2008).

\subsection{Prtumbuhan Tanaman Padi}

Pertumbuhan padi sejak bibit hingga panen melalui beberapa fase vegetatif cepat, vegetatif lambat, reproduksi dan pemasakan fase vegetatif cepat adalah : fase ini dimulai dari pertumbuhan bibit sampai jumlah anakan maksimum. Selama fase ini jumlah anakan, tinggi tanaman dan berat jerami ters bertambah. jumlah anakan maksimim biasanya dicapai pada minggu ke-6/7 setelah tanam. Jumlah anakan maksimum perbatang dapat digolongkan menjadi sangat rendah (kurang dari 5 batang), rendah (5-8 batang), tinggi (13- 16 batang), dan sangat tinggi (lebih dari 16 batang.

Fase vegetatif lambat adalah : fase ini dimulai saat jumlah anakan maksimum sampai keluarnya premordia (bakal malai). Premordia keluar biasanya pada umur 50 hari setelah tanam. pada fase ini beberapa anak akan mati, dengan demikian jumlah anakan menjadi berkurang. Tinggi tanaman dan berat jerami terus bertambah tetapi tidak secepat fase vegetatif cepat. Fase reproduksi adalah : fase ini dimulai dari keluarnya Premodia sampai malai berbunga. Tinggi dan berat jerami bertambah dengan cepat. Fase Pemasakan adalah : fase ini dimulai dari keluarnya bunga sampai saat panen. Berat malai bertambah dengan cepat, sedang berat jerami menurun (Anonimous, 1977).

\subsection{Varietas Padi}

Ciri khas suatu varietas sangat pentng untuk mengenal dan membedakan antara varietas satu dengan yang lain, yang digunakan untuk mengenal suatu varietas adalah dengan menggunakan deskripsi varietas yang bersangkutan. Varietas unggu Internasional dari Rice Research Institute (IRRI) filipina adalah jenis IR atau PB yaitu IR 22, IR 42, dan IR 54 (dataran rendah); PB 32, PB 34, PB 36 Dan PB 48, PB 42 cisadane, dan lantik bamban dan batang piaman (dataran rendah) (Dedi, 2004).

\subsection{Tanah Gambut}

Tanah gambut (Organosols = Histosols) terbentuk dari lapukan bahan organik terutama dari tumpukan sisa-sisa jaringan tumbuhan di masa lampau. Gambut merupakan sifat-sifat fisik yang perlu meendapat perhatian dalam pemanfaatan gambut.Berdasarkan atas tingkat pelapukkan (dekomposisi) tanah gambut dibedakan menjadi gambut kasar (Fibrist) yaitu gambut yang memiliki lebih dari $2 / 3$ bahan organik kasar, gambut sedang (hemist) memiliki 1/3$2 / 3$ bahan organik kasar dan gambut halus (saprist) jika bahan organik kasar kurang 
dari 1/3. Gambut kasar mempunyai porositas yang tinggi, gaya memegang air sangat tinggi, namun unsur hara masih dalam bentuk organik dan sulit tersedia bagi tanaman. Gambut kasar mudah mengalami penyusutan yang besar jika tanah direklamasi, Gambut halus memiliki ketersediaan unsur hara yang lebih tinggi memiliki kerapatan lindak yang lebih besar dari gambut kasar (Noor 2001).

\section{METODOLOGI PENELITIAN}

Penelitian ini dilaksanakan di Jalan SKB Tembilahan Kota Inhil Propinsi Riau, dari bulan Januari sampai dengan bulan Maret 2013. Bahan yang digunakan dalam penelitian ini adalah : benih padi Lantik Bamban , Batang Piaman, Ciherang, Cisadane, Pandan Wangi, Ripcord 3 EC, Urea, $\mathrm{KCL}$, SP 36, Alat yang di gunakan adalah: cangkul parang, meteran, gembor. Rancangan yang di gunakan pada penelitian ini adalah Rancangan Acak Kelompok (RAK) dengan 5 perlakuan dan 3 ulangan. Data yang diperoleh dianalisis secara statistik dengan menggunakan uji $F$ (Fisher's test). Apabila diperoleh hasil yang berbeda nyata maka dilanjutkan dengan TUKEY HSD.

\section{HASIL DAN PEMBAHASAN}

\subsection{Tinggi Tanaman Padi (cm)}

Hasil pengamatan terhadap tinggi tanaman setelahdilakukan analisis sidik ragam menunjukan hasil yang berbeda nyata. Untuk rerata tinggi tanaman padi masing-masing varietas dapat dilihat pada table 1 berikut.

Tabel 1 : Rerata tinggi beberapa varietas padi di lahan gambut

\begin{tabular}{lc}
\hline Varietas & Tinggi Tanaman Padi $(\mathrm{cm})$ \\
\hline Latik Bamban & $98,667 \mathrm{a}$ \\
Batang Piaman & $95,000 \mathrm{ab}$ \\
Ciherang & $85,000 \mathrm{~cd}$ \\
Cisadane & $78,333 \mathrm{~d}$ \\
Pandan Wangi & $88,333 \mathrm{bc}$ \\
\hline
\end{tabular}

Ket : Angka- angka yang diikuti huruf kecil yang sama tidak berbeda nyata pada taraf 5 $\%$ menurut uji TUKEY Hsd

Dari tabel diatas dapat dilihat bahwa tinggi tanaman yang tertinggi yaitu pada varietas Lantik Bamban, Batang Piaman berbeda nyata dengan varietas, Ciherang, Cisadane dan Pandan Wangi. Kalau di bandingkan dengan deskripsinya kelima varietas tanaman padi masih di bawah deskripsi dan tidak mencapai pertumbuhan yang maksimum hal ini sebagai akibat tekanan kesuburan tanah gambut yang rendah. Perbedaan tinggi tanaman antara satu varietas lainnya adalah karena perbedaan genetik. hal ini sesuai dengan pendapat sitompul dan Guritno (1995) yang menyatakan bahwa perbedaan susunan genetik merupakan salah satu faktor penyebab keragaman penampilan tanaman.

\subsection{Jumlah Anakan Produktif ( batang )}

Hasil pengamatan terhadap jumlah anakan produktif pada tanaman padi setelah dilakukan analisis sidik ragam menunjukkan hasil yang tidak berbeda nyata. Rerata jumlah anakan produktif tanaman padi masing- masing varietas dapat dilihat pada tabel berikut ini.

Tabel 2 : Rerata Jumlah Anakan Produuktif Beberapa Varietas Padi Di Lahan Gambut.

\begin{tabular}{lc}
\hline Varietas Jumlah Anakan Produktif (batang) \\
\hline Latik Bamban & $15,000 \mathrm{a}$ \\
Batang Piaman & $16,167 \mathrm{a}$ \\
Ciherang & $16,167 \mathrm{a}$ \\
Cisadane & $17,333 \mathrm{a}$ \\
Pandan Wangi & $15,000 \mathrm{a}$
\end{tabular}

Ket : Angka- angka yang diikuti huruf kecil yang sama tidak berbeda nyata pada taraf 5 \% menurut uji TUKEY Hsd

Dari tabel di atas dapat dilihat bahwa jumlah anakan produktif kelima varietas tanaman padi tidak berbeda nyata satu sama lainnya. Namun secara angka jumlah anakan 
produktif yang terbanyak adalah varietas Cisadane (17,333 batang) diikuti oleh Batang Piaman (16, 167 batang), Ciherang (16,167 batang), Lantik Bamban (15,000 batang) dan Pandan Wangi (15,000 batang). Presentase kemampuan kelima varietas unggul menghasilkan jumlah anakan maksimum jumlah anakan produktif berkisar antara 1420 batang perumpun. Hal ini diduga disebabkan karna rendahnya ketersediaan $\mathrm{P}$ pada tanah gambut.

\subsection{Jumlah Malai Perumpun}

Pengamatan terhadap jumlah malai perumpun setelah dilakukan analisis sidik ragam menunjukkan hasil yang berbeda nyata. Untuk rerata jumlah malai perumpun pada masing-masing varietas dapat dilihat pada tabel berikut ini.

Tabel 3 : Reratajumlah Malai Beberapa Varieta Padi Di Lahan Gambut.

\begin{tabular}{lc}
\hline Varietas & Tinggi Tanaman Padi $(\mathrm{cm})$ \\
\hline Latik Bamban & $15,000 \mathrm{~b}$ \\
Batang Piaman & $15,000 \mathrm{~b}$ \\
Ciherang & $16,333 \mathrm{ab}$ \\
Cisadane & $18,000 \mathrm{a}$ \\
Pandan Wangi & $16,333 \mathrm{ab}$
\end{tabular}

Ket : Angka- angka yang diikuti huruf kecil yang sama tidak berbeda nyata pada taraf 5 $\%$ menurut uji TUKEY Hsd

Dari tabel diatas dapat dilihat bahwa Varietas Cisadane, Cierang, Pandan Wanggai sangat berbeda nyata dengan Varietas Latik Bamban, Batang Piaman. Jumlah gabah bernas perempuan yang tertinggi adalah pada varietas Cisadane berbeda nyata dengan varietas lainnya. Jumlah bibit per rumpun yang ditanam pada masing-masing varietas mempengaruhi jumlah malai per rumpun.

Jumlah gabah bernas permalai yang dihasilkan selaras dengan jumlah anakan. Pada hasil analisis jumlah anakan per rumpun terlihat bahwa hasil relatif sama dengan jumlah malai per rumpun. Pada tanaman yang mempunyai jumlah anakan banyak, fotosintesis akan lebih banyak fotosintesis akan lebih banyak pada batas tertentu. Sehingga fotosintesis yang dihasilkan menjadi banyak yang dapat mempengaruhi pembentukan malai. Yos Sutiyoso (1999) menyatakan bahwa tanaman yang cukup dalam melakukan fotosintesis akan memiliki perkarakan yang berkembang dengan baik, jumlah anakan yang banyak, serta akhirnya dapat berpengaruh terhadap gabah bernas permalai.

\subsection{Jumlah Gabah Bernas Permalai}

Hasil pengamatan terhadap jumlah gabah bernas permalai pada tanaman padi setelah dilakukan analisis sidik ragam menunjukkan hasil yang tidak berbeda nyata.Untuk rerata jumlah gabah bernas permalai tanaman padi masing-masing varietas dapat dilihat pada tabel berikut ini.

Tabel 4 : Rerata Jumlah Gabah Bernas Permalai

\begin{tabular}{ll}
\hline Varietas & $\begin{array}{l}\text { Jumlah Gabah Bernas } \\
\text { Permala (gabah) }\end{array}$ \\
\hline Latik Bamban & $55,000 \mathrm{a}$ \\
Batang Piaman & $60,000 \mathrm{a}$ \\
Ciherang & $57,333 \mathrm{a}$ \\
Cisadane & $56,000 \mathrm{a}$ \\
Pandan Wangi & $56,000 \mathrm{a}$ \\
\hline
\end{tabular}

Ket : Angka- angka yang diikuti huruf kecil yang sama tidak berbeda nyata pada taraf 5 $\%$ menurut uji TUKEY Hsd

Dari tabel diatas dapat dilihat bahwa jumlahgabah bernas permalai tinggi yaitu pada varietas Batang Piaman dengan jumlah 60,000 tetapi tidak berbeda nyata dengan varietas yang lainnya. Hal ini juga sangat erat kaitannya dengan jumlah anakan produktif, yang tiap varietasnya hanya mampu menghasilkan 50\% anakan, sehingga lebih banyak assimilat yang dipergunakan untuk pertumbuhan jumlah anakan produktif yang menyebabkan jumlah gabah bernas 
perumpun yang dihasilkan sedikit. Sesuai dengan pendapat Zaeny, (2007) bahwa interaksi antara tanaman padi dengan faktor lingkungan serta antara faktor lingkungan itu sendiri bisa mempengaruhi pertumbuhan dan hasil padi. Salah satunya faktor lingkungan yaitu tanah, karena tanah merupakan media bagi tanaman yang mampu memberikan ketersediaan unsur hara yag menjadi sumber makanan dan nutrisi bagi tanaman.

\subsection{Jumlah Gabah Bernas Perumpun}

Hasil pengamatan terhadap jumlah gabah bernas perumpun pada tanaman padi setelah dilakukan analisis sidik ragam menunjukkan hasil yang tidak berbeda nyata. Untuk rerata jumlah gabah bernas prumpun tanaman padi masing-masing varietas dapat dilihat pada tabel berikut ini.

Tabel 5 Jumlah Gabah Bernas Perumpun

\begin{tabular}{lc}
\hline Varietas & Tinggi Tanaman Padi $(\mathrm{cm})$ \\
\hline Latik Bamban & $98,667 \mathrm{a}$ \\
Batang Piaman & $95,000 \mathrm{ab}$ \\
Ciherang & $85,000 \mathrm{~cd}$ \\
Cisadane & $78,333 \mathrm{~d}$ \\
Pandan Wangi & $88,333 \mathrm{bc}$
\end{tabular}

Ket : Angka- angka yang diikuti huruf kecil yang sama tidak berbeda nyata pada taraf 5 $\%$ menurut uji TUKEY Hsd

Dari tabel diatas dapat dilihat bahwa jumlah produksi tanaman padi perplot tertinggi yaitu pada varietas Cisadane dengan jumlah 1.008,931 (butir) tetapi tidak berbeda nyata dengan varietas lainnya.

Menurut Suyamto, dkk. (2007) varietas unggul merupakan salah satu teknologi yang berperan penting dalam meningkatkan kuantitas dan kualitas padi nasional antara lain tercermin dari pencapaian swasembada beras pada tahun 1984.Sesuai pendapat Amilin (2001) menyatakan bahwa setiap varietas mempunyai nilai duga herbialitas tinggi, maka keragaman sifat tersebut disebabkan oleh genetik dan bukan oleh faktor lingkungan, dan biasanya dikendalikan oleh suatu gen sebaliknya juka sesuatu sifat mempunyai nilai duga herbalitas rendah, maka keragaman sifat tersebut banyak dipengaruhi oleh faktor lingkungan dan biasanya sifat ini dikendalikan oleh banyak gen.

\section{KESIMPULAN DAN SARAN}

\subsection{Kesimpulan}

1. Pertumbuhan dan produksi padi yang lebih baik ditanam di tanah gambut adalah varietas cisadane dengan jumlah gabah bernas perumpun $1.008,931$ (butir)

2. Varietas yang lebih toleran ditanam di gambut adalah varietas Cisadane

\subsection{Saran}

1. Budidaya padi di lahan gambut disarankan untuk menanam varietas Ciasdane.

2. Perlu dilakukan penelitian lanjut untuk menanam padi dengan sistem jajar legowo pada varietas Cisadane.

\section{DAFTAR PUSTAKA}

Anonimus, 1977. Deskripsi Varietas UnggulBIU Padi. Badan Litban Pertanian. balai penelitian Tanaman Padi.

BPS, 2010. Statistik Indonesia. biro pusat statistik

Dedi 2004. ciri khas suatu varietas padi toleran salinitas pada lahan rawarawa di kabupaten Pesisir Selatan. J. Agron. Indonesia 37 (2): 101-106.

Haryoko, W. 2006. Pengaruh umur bibit terhadap pertumbuhan dan produksi padi pada sawah gambut. Laporan Penelitian LP3M Universitas Tamansiswa. padang

Surowinoto, 1980. Perkembangan akar tanaman padi di indonesia. jakarta

Van Steenis. 1981. Floristic Altitudinal Zones in Malesia. Botanical Journal 89: 289- 
292. http://online library. wiley. com/.[10 April 2010]. Vega,

Wikipedia, 2011. Pedoman Bercocok Tanam Padi, Palawija, Sayursayuran. Badan Pengendali Bimas. Jakarta. 